\title{
Water metabolism and postconcussional symptoms 5 weeks after mild head injury
}

Citation for published version (APA):

Bohnen, N., Twijnstra, A., \& Jolles, J. (1993). Water metabolism and postconcussional symptoms 5 weeks after mild head injury. European Neurology, 33(1), 77-79. https://doi.org/10.1159/000116907

Document status and date:

Published: 01/01/1993

DOI:

10.1159/000116907

Document Version:

Publisher's PDF, also known as Version of record

\section{Please check the document version of this publication:}

- A submitted manuscript is the version of the article upon submission and before peer-review. There can be important differences between the submitted version and the official published version of record.

People interested in the research are advised to contact the author for the final version of the publication, or visit the DOI to the publisher's website.

- The final author version and the galley proof are versions of the publication after peer review.

- The final published version features the final layout of the paper including the volume, issue and page numbers.

Link to publication

\footnotetext{
General rights rights.

- You may freely distribute the URL identifying the publication in the public portal. please follow below link for the End User Agreement:

www.umlib.nl/taverne-license

Take down policy

If you believe that this document breaches copyright please contact us at:

repository@maastrichtuniversity.nl

providing details and we will investigate your claim.
}

Copyright and moral rights for the publications made accessible in the public portal are retained by the authors and/or other copyright owners and it is a condition of accessing publications that users recognise and abide by the legal requirements associated with these

- Users may download and print one copy of any publication from the public portal for the purpose of private study or research.

- You may not further distribute the material or use it for any profit-making activity or commercial gain

If the publication is distributed under the terms of Article $25 \mathrm{fa}$ of the Dutch Copyright Act, indicated by the "Taverne" license above, 
N. Bohnen ${ }^{\mathrm{a}}$

1. Twijnstrab

1. Jolles ${ }^{\mathrm{a}}$

Department of Neuropsychology and

Psychobiology, University of Limburg, Maastricht;

Department of Neurology, University

Hospital Maastricht, The Netherlands

\section{Water Metabolism and Postconcussional Symptoms 5 Weeks after Mild Head Injury}

\section{Key Words}

Water metabolism

Postconcussive syndrome

Mild head injury

\begin{abstract}
Posttraumatic diabetes insipidus has been reported as a sequela to head injury. It is unknown whether subclinical types of diabetes insipidus, or other types of water metabolism disorders, occur after mild head injury (MHI) and, if so, whether they are related to the persistence of postconcussional symptoms. MHI patients $(\mathrm{n}=38)$ were screened for disturbances of water metabolism by comparing plasma and urine osmolalities at about 5 weeks after the trauma. Eight patients had evidence of an increased plasma osmolality together with a relatively decreased urine osmolality after an overnight fast. The presence of this disturbance was significantly related to the persistence of postconcussional symptoms. The results suggest that subclinical disturbances of water metabolism may, among other factors, be related to the persistence of symptoms after MHI.
\end{abstract} ......................

\section{Introduction}

Posttraumatic diabetes insipidus has been reported as an uncommon sequela to head injury [1,2]. Complete or partial deficiency in the release of arginine-vasopressin into the blood may indicate a dysfunction of the posterior pituitary and/or hypothalamus. There are case studies reporting the presence of (partial) diabetes insipidus after mild head injury (MHI) without evidence of a skull fracture [2-4]. Notman et al. [2] described a rapid method to screen for disturbances of water metabolism, such as diabetes insipidus, by comparing plasma and urine osmolalities. The data can be plotted graphically and compared with data obtained from healthy individuals. In normal subjects there is a positive relationship between increasing plasma and urine osmolality. Patients with partial dia- betes insipidus can concentrate their urine to give osmolality values higher than those of plasma, but the rate of increase in urine osmolality is either lower than that of normal subjects or is similar to that of normal subjects but shifted to the right. Thus, a high plasma osmolality is necessary for an adequate concentration of the urine [5].

Although overt types of diabetes insipidus are uncommon after head injury, there is circumstantial evidence that MHI patients may temporarily complain of increased thirst with mild polyuria for weeks or months after the injury.

It was the aim of the present study to assess whether subclinical disturbances of water metabolism occur in MHI patients. We also investigated whether a disturbance of water metabolism is related to the persistence of postconcussional symptoms (PCS) after MHI. A screening test

Received:
September 9, 1991
Accepted:

February 24, 1992
N. Bohnen, MD

Department of Neuropsychology and Psychobiology

University of Limburg

P.O. Box 616

NL-6200 MD Maastricht (The Netherlands) (c) 1993 S. Karger AG, Base $00|4-3022 / 93 / 033|-0077$ $\$ 2.75 \%$ 


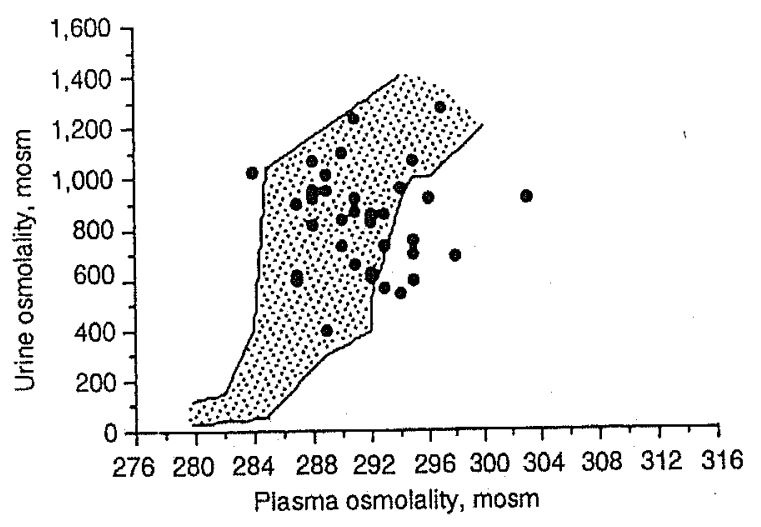

Fig. 1. The relationship between plasma and urine osmolality after an overnight fast. The range of normative values of related plasma and urine osmolalities in nonconcussed subjects $<40$ years is represented by the grey area. Patients with a plasma osmolality $\geqslant 295 \mathrm{mosm} / \mathrm{kg}$ water together with an urine osmolality $<1,000 \mathrm{mosm} / \mathrm{kg}$ water are considered to have a reduced renal capacity to concentrate urine after an overnight fast. $\bullet=$ Patient data.

Table 1. Results of the screening test for disturbances of water metabolism in relationship to the number of patients who reported no/few, or $\geqslant 3$ PCS

\begin{tabular}{lccc}
\hline & No or $1-2$ PCS & $\geqslant 3$ PCS & Total \\
\hline Test - & 22 & 8 & 30 \\
Test + & 2 & 6 & 8 \\
Total & 24 & 14 & 38 \\
\hline
\end{tabular}

$\mathrm{p}<0.05$.

for disturbances of water metabolism, developed by Notman et al. [2], was applied to patients with mild head injury at about 5 weeks after the trauma.

\section{Patients and Methods}

\section{Subjects}

Patients who had sustained an MHI were selected on the basis of the following eligibility criteria: a period of unconsciousness ranging from several seconds to $15 \mathrm{~min}$; posttraumatic amnesia for $<60$ min, and an EMV (Glasgow coma score) of 15 on admission. Patients were excluded if one of the following criteria was met: evi- dence of a focal neurological deficit or a skull fracture; intoxication at the time of the accident, or a history of preexisting emotional problems. Thirty-eight patients ( 18 females and 20 males; mean age 26.9 \pm 13.8 years) were selected and examined at about 5 weeks (4-6 weeks) after the trauma. All subjects were free from medication known to affect renal function adversely. As renal function may change with age [6] the study was restricted to subjects $<40$ years old. The study was approved by the ethical council of the University Hospital and all subjects gave their informed consent.

\section{Postconcussive Symptoms}

A checklist of PCS was completed, which included items of headache, dizziness, nausea, irritability, difficulties with concentration and memory, fatigue, sleep disturbances, and blurred vision. As these symptoms may also occur in healthy individuals [7], the symptoms were scored for the absolutely or relatively increased appearance after the injury in comparison with the pretraumatic condition.

Patients were divided into two groups 5 weeks after injury. The first group consisted of patients with $\geqslant 3$ PCS at 5 weeks (high-symptom endorsers), whereas the second group had no or only 1-2 PCS at this time (low-symptom endorsers) [8].

\section{Procedure}

Fasting urine and plasma samples were determined for osmolal ity and compared with normal values obtained from nonconcussed controls. Each subject was instructed not to take anything by mouth from midnight until the next morning when blood was collected between 08.30 and 09.30 . For ethical reasons related to the discom fort of a full bladder, fasting urine was collected after awakening. The maximal interval between the collection of urine and venipuncture was $1-1.5 \mathrm{~h}$. This delay is not considered a relevant biasing facto because there is an asymptotic relationship between the increase urine osmolality and the duration of continued fasting, with levelso urine osmolality gradually reaching a plateau [9].

Osmolality was measured by freezing-point depression (Gonoth Osmomat 030). Each sample was measured immediately in trip: cate, after plasma separation and repeated calibration of the osmon eter before each assay (the coefficient of variation was $<0.2 \%$ ), T) range of normal values for the relationship between plasma and unin osmolality after an overnight fast obtained from 62 nonconcuss. healthy subjects (aged $<40$ years) is depicted in grey in figure There were normal nonconcussed subjects with a fasting plasp osmolality $>295 \mathrm{mosm} / \mathrm{kg}$ water together with maximally cond trated urine $(>1,000 \mathrm{mosm} / \mathrm{kg})[10,11]$. Therefore, we definet (slight) disturbance of water metabolism as a plasma osmoffyt: $\geqslant 295 \mathrm{mosm} / \mathrm{kg}$ water together with an urine osmolali $<1,000 \mathrm{mosm} / \mathrm{kg}$ water. There were 2 control subjects who hady ues that fell just outside these limits.

\section{Results}

There were 24 patients who had no or only 1-2 PCS 5 weeks after an MHI (low-symptom endorsers), where 14 patients still complained of $\geqslant 3$ symptoms at this tiin (high-symptom endorsers). There were 8 patients with submaximally concentrated urine in comparison with $t_{1}$ nonconcussed subjects (plasma osmolality $>294$ mos 
$\mathrm{kg}$ water and urine osmolality $<1,000 \mathrm{mosm} / \mathrm{kg}$ water). The mean plasma and urine osmolality of these 8 patients was $297.3( \pm 2.9)$ and $816.9( \pm 148.7)$, respectively. Patients with a negative test $(\mathrm{n}=24)$ had corresponding values of $290.5( \pm 2.8)$ and $815.7( \pm 208.7)$. There were no patients who produced hypotonic urine relative to the osmolality of their plasma. Thus, none of the patients had evidence of a moderate to severe type of diabetes insipidus.

As can be seen from the contingency table (table 1) there was a significant relationship between the presence of a subclinical disturbance of water metabolism after an 6 vernight fast and the number of high-symptom endorsers at 5 weeks after the trauma (continuity-adjusted $\chi^{2}=$ 4. 43; $\mathrm{p}<0.05$ ). Patients with a subclinical disturbance of water metabolism had a relative risk (odds ratio) of 8.25 of having $\geqslant 3$ PCS 5 weeks after MHI $(95 \%$ confidence limits: 1.4-40.6).

\section{Discussion}

There is no information available about the incidence of subclinical disturbances of water metabolism after MHI. Miller et al. [12] demonstrated that disturbances in water metabolism due to a deficiency in vasopressin covered a wide spectrum, ranging from severe polyuria and hypotonic urine to a scarcely noticeable or significant polyuria with a maximal urine osmolality similar to that of normal subjects. In the present study, none of the 38 patients with uncomplicated MHI had evidence of a moderate to severe type of diabetes insipidus after the trauma injury, but 8 patients had evidence of subclinical disturbances of water metabolism. These had an 8.25-fold higher risk of persistent PCS 5 weeks after MHI than patients without evidence of a disturbed water metabolism. It should be emphasized, however, that the pathogenesis of the PCS may be related to multiple factors, and that it is not reasonable to explain the occurrence of PCS by one factor alone $[7,8]$.

It should also be mentioned that the mesurement of urine osmolality may not be the most sensitive way to assess the concentrating capacity of the kidneys, as urine osmolality also depends on dietary factors that do not influence body tonicity, such as ammonium salts and urea. It is likely that the sensitivity of a screening test for subclinical disturbances of water metabolism may be increased by specifically measuring sodium and chloride levels in urine and plasma [10]. Although partial diabetes insipidus is usually characterized by a normal or increased plasma osmolality with a decreased urine osmolality, measurements of vasopressin and other hormones are necessary to establish this diagnosis.

In summary, subclinical disturbances of water metabolism may be related, among other factors, to the persistence of postconcussive sequelae after MHI. Further research is needed to investigate whether traumatic damage to the posterior pituitary and/or hypothalamus is a pathogenetic factor for the postconcussive syndrome.

\section{References}

1 Porter RJ, Miller RA: Diabetes insipidus following closed-head injury. J Neurol Neurosurg Psychiatry 1948;11:258-262.

2 Notman DD, Mortek MA, Moses AM: Permanent diabetes insipidus following head trauma: Observations on ten patients and an approach to diagnosis. J Trauma 1980;20:599-602.

3 Kern KB, Meislin HW: Diabetes insipidus: Occurrence after minor head injury. J Trauma 1984;24:69-72.

4 Bohnen N, Twijnstra A, Terwel D, Jolles J: Csf arginine-vasopressin decreases during dehydration in a patient with post-traumatic diabetes insipidus. Horm Metab Res 1990;22: 508-509.
5 Miller M, Moses AM: Clinical states due to alteration of $\mathrm{ADH}$ release and action; in Moses AM, Share L (eds): Neurohypophysis. Basel, Karger, 1977, pp 153-166.

6 Rowe JW: Aging and renal function; in Arieff AL, Defronzo RA (eds): Fluid, Electrolyte, and Acid-Base Disorders. New York, Churchill Livingstone, 1985, vol. 2, pp 1231-1246.

7 Dikmen S, Maclean A, Temkin N: Neuropsychological and psychosocial consequences of minor head injury. J Neurol Neurosurg Psychiatry 1986;49:1227-1232.

8 Dikmen S, Temkin N, Armsden G: Neuropsychological recovery: Relationship to psychosocial functioning and postconcussive complaints; in Levin HS, Eisenberg HM, Benton AL (eds): Mild Head Injury. New York, Oxford University Press, 1989, pp 229-241.
9 Cox M, Geheb M, Singer I: Disorders of thirst and renal water excretion; in Arieff $\mathrm{AL}, \mathrm{De}$ fronzo RA (eds): Fluid, Electrolyte, and AcidBase Disorders. New York, Churchill Livingstone, 1985, vol 1, pp 119-183.

10 Halperin ML, Skorecki KL: Interpretation of the urine electrolytes and osmolality in the regulation of body fluid tonicity. Am J Nephrol 1986;6:241-245.

11 Baylis PH: Osmoregulation and control of vasopressin secretion in healthy humans. Am J Physiol 1987;253:R671-R678.

12 Miller M, Dalakos T, Moses AM, Fellerman H, Streeten DHP: Recognition of partial defects in antidiuretic hormone secretion. Ann Intern Med 1970;73:721-729. 